ECS Transactions, 68 (1) 569-577 (2015)

10.1149/06801.0569ecst @The Electrochemical Society

\title{
Study of 2R-Cell Equipped with LSC and LSCF Cathodes under Thermic and Redox Cycling
}

\author{
Pierre Coquoz $^{\mathrm{a}}$, Carolina Grize ${ }^{\mathrm{a}}$, Jesus Ruiz ${ }^{\mathrm{a}}$, Anaïs Bourradou ${ }^{\mathrm{a}}$, Stefan Diethelm ${ }^{\mathrm{b}}$ \\ Vaibhav Singh ${ }^{\mathrm{b}}$ and Raphaël Ihringer ${ }^{\mathrm{a}}$ \\ ${ }^{\mathrm{a}}$ Fiaxell Sàrl, EPFL Science Parc, PSE A, 1015 Lausanne, Switzerland \\ ${ }^{b}$ SCI-STI-JVH, EPFL, 1015 Lausanne, Switzerland
}

In this article we present the results of $2 \mathrm{R}-\mathrm{Cell}$, developed by Fiaxell, tested under thermic and redox cycles. Different cathodes were studied, composite LSC-GDC and LSCF, and degradation due to multiple thermic and redox cycles was observed. Three composite LSC-GDC cathodes were tested (40, 60 and $75 \%$ GDC). The highest current density was achieved by the cathode with $75 \%$ amount of GDC, at $1060\left[\mathrm{~mA} / \mathrm{cm}^{2}\right]$ at $0.8 \mathrm{~V}$ and $780^{\circ} \mathrm{C}$, before thermic cycling. This cell underwent 40 thermic cycles with an average power loss of $0.7 \%$ per cycle. A LSCF cathode equipped 2R-Cell, tested by EPFL, our partner in an EU project (Roxsolidcell), was subjected to 20 thermic cycles and 20 redox cycles. With this cathode material the average ASR increase was $0.3 \%$ per thermic cycle and $0.5 \%$ per redox cycle. SEM pictures of the tested cells after thermic and redox cycles are presented and discussed.

\section{Introduction}

SOFC technologies have evolved mainly in two distinct branches. One is based on electrolyte supported cells (ESC) with operating temperature of $750-900^{\circ} \mathrm{C}$ and the other integrates anode supported cells (ASC) with thin electrolyte. The latter provides better overall performances and allows for operation in a wide range of temperature (600$850^{\circ} \mathrm{C}$ ). However, ASC suffer from an important problem: they are totally destroyed if re-oxidation occurs on the anode. This happens, for instance, when fuel supply inappropriately stops or when peripheral re-oxidation occurs. In all cases, when reoxidation starts, the cell quickly undergoes fatal destruction. In order to overcome this major limitation, Fiaxell Sàrl has developed a novel anode supported thin electrolyte, the $2 \mathrm{R}-\mathrm{Ce} \mathrm{ll}^{\mathrm{TM}}$, that provides robustness and reliability upon multi thermo (TC) and redoxcycles (RC) (Figure 1). A complete discussion on the stability of $2 \mathrm{R}-\mathrm{Ce}$ - ${ }^{\mathrm{TM}}$ over full TC and $\mathrm{RC}$ without any failure neither in the anode substrate nor in the thin electrolyte have been published elsewhere $(1,2,3)$.

In order to improve the cell performance, LSC based cathodes, known for their high activity, have been investigated. LSC material, due to its high thermal expansion coefficient, can bring mismatches with the other layer and induce delamination when the cell undergoes a thermic cycle. This is what happens for instance during a shutdown and a restart of a real system. For this reason different amounts of ceria have been added to the LSC cathode to reduce the risk of delamination under these conditions. Resistance to 
TC and RC of a 2R-Cell with a pure LSCF cathode is discussed and compared to the LSC cathode results. The experiment on the LSCF cathode was done at EPFL, and included 20 thermic cycles and 20 redox cycles.

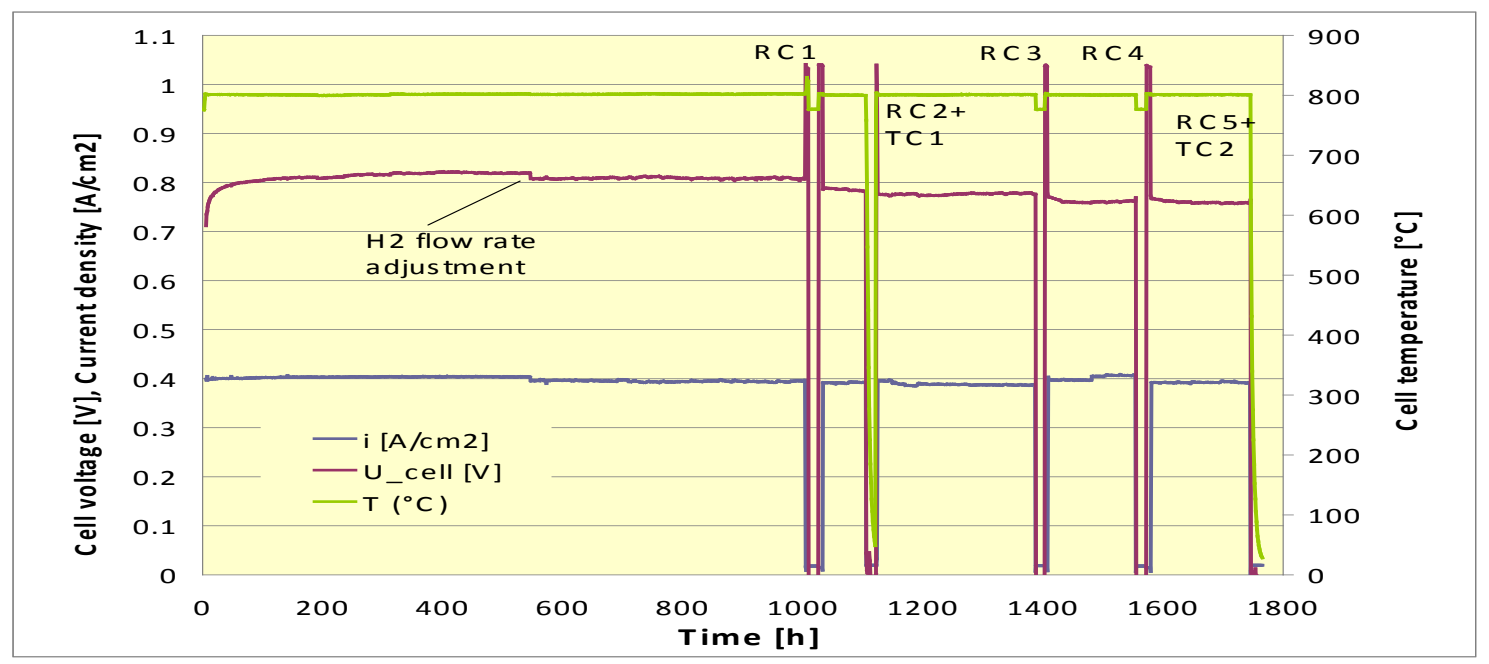

Figure 1. 1800 hours test done by LENI at EPFL (2013) of a 2R-Cell with LSM/8YSZ cathode. The cell was subjected to 5 redox cycles and 2 thermic cycles without any failure.

\section{Experimental}

\section{Cell Fabrication}

2R-Cell ${ }^{\mathrm{TM}}$ substrates are prepared with $\mathrm{NiO}$ and $8 \mathrm{YSZ}$ in water dispersion and water soluble polymer paste via proprietary tape casting technique $(1,2,3)$. Functional layers are then screen printed on the substrate. The $2 \mathrm{R}-\mathrm{Cells} \mathrm{s}^{\mathrm{TM}}$ are sintered at $1300-1380{ }^{\circ} \mathrm{C}$ for a few hours. The result of the process is half cells, with surface area of 10 to $150 \mathrm{~cm}^{2}$ and thickness of 0.25 to $0.5 \mathrm{~mm}$.

Ceria Buffer Layer. In order to use LSC based cathodes, a protective ceria buffer layer ( $20 \%$ mol. gadolinium doped ceria, GDC) is used to avoid reactions between electrolyte and cathode. A thin layer of ceria ink (20GDC with $1-2 \%$ weight of $\mathrm{CoO}$ ) is screen printed on the sintered half-cell and post-sintered at $1100-1250{ }^{\circ} \mathrm{C}$ for a few hours.

Cathode. LSC based cathodes were composed of one composite layer (LSC-GDC) and one layer of pure cathode material for current collection $\left(\mathrm{La}_{0.5} \mathrm{Sr}_{0.5} \mathrm{CoO}_{3}\right)$. Composite layers with different GDC (20\% mol. Gadolinia doped) proportions were used (40-75\% wt.). The LSCF cathode contained only pure LSCF $\left(\mathrm{La}_{0.6} \mathrm{Sr}_{0.4} \mathrm{Co}_{0.2} \mathrm{Fe}_{0.8} \mathrm{O}_{3}\right)$. The layers are screen printed and then sintered at $1000-1100{ }^{\circ} \mathrm{C}$ for a few hours. The diameter of cells was $60 \mathrm{~mm}$ with a cathode diameter of $36 \mathrm{~mm}\left(10.2 \mathrm{~cm}^{2}\right)$.

\section{Thermic Cycles}

Cells were operated at $780^{\circ} \mathrm{C}$ with $180 \mathrm{ml} / \mathrm{min}$ of dry $\mathrm{H}_{2}$. For the thermic cycle the furnace is stopped and the $\mathrm{H}_{2}$ replaced by Formiergas $\left(92 \% \mathrm{~N}_{2}+8 \% \mathrm{H}_{2}\right.$ ). The cell cools down to room temperature, then is reheated to $780^{\circ} \mathrm{C}$ at $250{ }^{\circ} \mathrm{C} / \mathrm{h}$ till $300^{\circ} \mathrm{C}$ and $300{ }^{\circ} \mathrm{C} / \mathrm{h}$ 
till working temperature. Finally the fuel is switched back to $\mathrm{H}_{2}$ when the working temperature is reached.

\section{$\underline{\text { Area Specific Resistance }}$}

The computation of the area specific resistance is done with the equation:

$$
A S R_{\tan }=\frac{-\left(U_{i+1}-U_{i-1}\right)}{j_{i+1}-j_{i-1}}
$$

$j$ is the current $\left[\mathrm{mA} / \mathrm{cm}^{2}\right]$ and $U$ the cell voltage at the current $j[\mathrm{mV}]$. The increment corresponds to $0.1 \mathrm{~A} / \mathrm{cm}^{2}$.

\section{$\underline{\text { Sintering Temperature }}$}

The sintering temperature for cathode was $1000^{\circ} \mathrm{C}$, as in a previous article where a LSC-GDC based cathode was used on a 2R-Cell (1). Different temperature were tested, but only gave detrimental results. For instance a cell sintered at $1100^{\circ} \mathrm{C}$ had a very low current density $\left(60 \mathrm{~mA} / \mathrm{cm}^{2}\right.$ at $0.8 \mathrm{~V}$ and $\left.780^{\circ} \mathrm{C}\right)$.
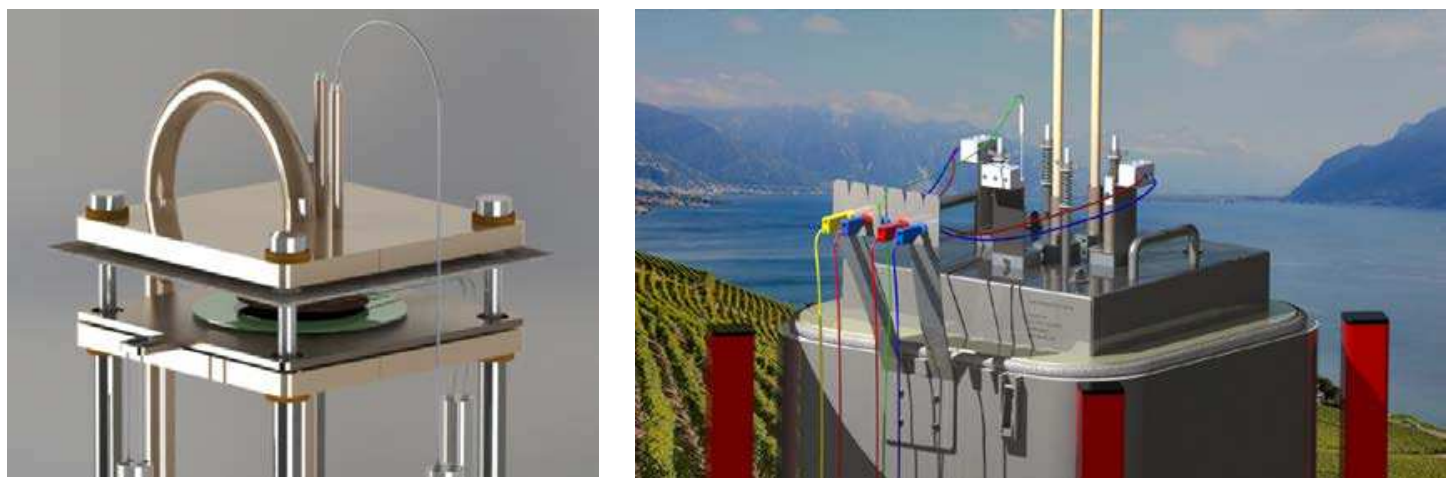

Figure 2. Left: Exploded view of the set up head. Right: Drawing of the Open Flanges ${ }^{\mathrm{TM}}$ Set-Up developed by Fiaxell in a furnace.

\section{Electrochemical Test in the Open Flanges Set-up}

All electrochemical measurements have been carried out in the Open Flanges ${ }^{\mathrm{TM}}$ SetUp that has been developed and commercialized by Fiaxell Sàrl (figure 2). This test rig allows for a simple and rapid mounting of cells of different sizes, ranging from $20 \mathrm{~mm}$ to $80 \mathrm{~mm}$ in diameter, and gives highly reproducible results. The distinctiveness of the Open Flanges ${ }^{\mathrm{TM}}$ Set-Up is that no sealing is required.

The SOFC cell is simply squeezed between two alumina felts and the pressure is kept constant during the whole experiment thanks to 4 calibrated external springs. The current collection is provided by nickel foam on the anode side and gold M_Grid ${ }^{\mathrm{TM}}$ on the cathode side (Figure 2). A fuel flow rate of 120 to 200 ( $\mathrm{ml} / \mathrm{min}$ ), depending on the cell size, is enough to ensure an OCV close to the theoretical value. Furthermore the set-up can be adapted for hydrolysis, by adding a specific in situ steamer (contrary to an external steamer which needs heated tubes to avoid condensation). The latter also allows performing experiments with carbon or liquid fuel. 


\section{Results and Discussion}

\section{$\underline{\text { LSC-GDC Cathodes }}$}

60LSC-40GDC. Different proportions of GDC were used for the composite layer. The first cell, equipped with a composite cathode 60LSC-40GDC, was subjected to 14 thermic cycles (cell 143.17). Before the cycles, the cell produced a current density of 986 $\left[\mathrm{mA} / \mathrm{cm}^{2}\right]$ at $0.8 \mathrm{~V}$ and $780^{\circ} \mathrm{C}$, which corresponds to a power density of $789\left[\mathrm{~mW} / \mathrm{cm}^{2}\right]$.

After $10 \mathrm{TC}$ the current density decreased from 986 to $835\left[\mathrm{~mA} / \mathrm{cm}^{2}\right]\left(0.8 \mathrm{~V}, 780^{\circ} \mathrm{C}\right)$ representing a loss of $1.5 \%$ per cycle. When the cell was removed from the set-up a piece of the cathode detached from the cell being stuck in the current collecting gold grid. It indicates a delamination between the cathode and the ceria barrier layer, which could explain the decrease of performances during thermic cycles.

40LSC-60GDC. In order to avoid this problem and to create a lower chemical gradient between the ceria barrier layer and the cathode, the proportion of GDC was increased from 40 to $60 \%$ in the composite layer (cell 143.111). It was subjected to 10 thermic cycles. The initial current density was higher than the 60LSC-40GDC cell at 1050 $\left[\mathrm{mA} / \mathrm{cm}^{2}\right]$ at $0.8 \mathrm{~V}$ and $780^{\circ} \mathrm{C}$, corresponding to a power density of $840\left[\mathrm{~mW} / \mathrm{cm}^{2}\right]$. The degradation rate was similar to the 60LSC-40GDC cell (Figure 3 and 8). The total current density decreased from 1050 to $870\left[\mathrm{~mA} / \mathrm{cm}^{2}\right]$ after the $10 \mathrm{TC}$. The cell suffered a power and current density loss of $1.7 \%$ per cycle, which is slightly higher than what has been observed for the 60LSC-40GDC cell $(1.5 \%)$, contrary to what was expected.

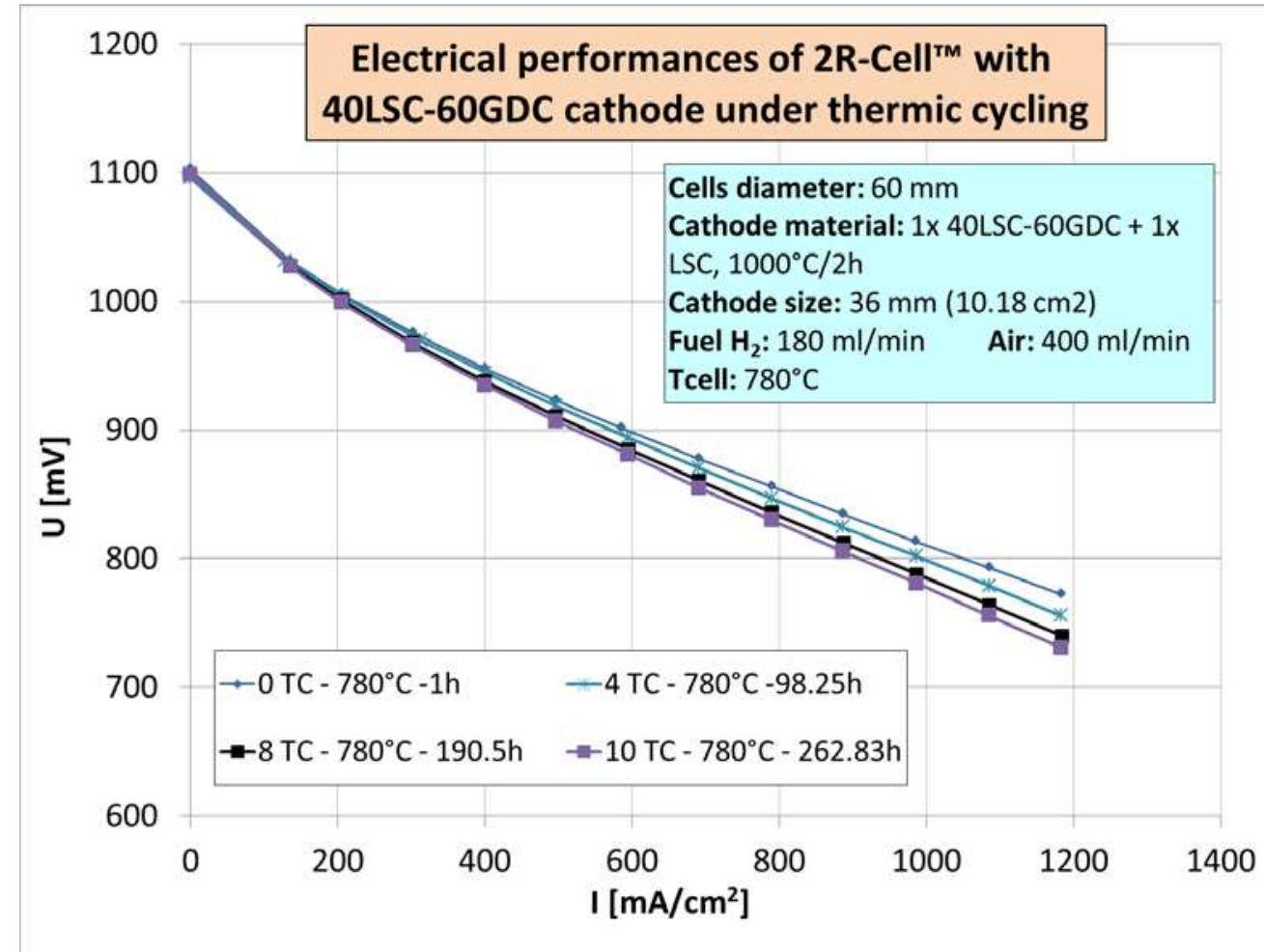

Figure 3. 2R-Cell with 40LSC-60GDC cathode. After 10 thermic cycles the average current density loss per cycle is $1.7 \%\left(0.8 \mathrm{~V}, 780^{\circ} \mathrm{C}\right)$. 


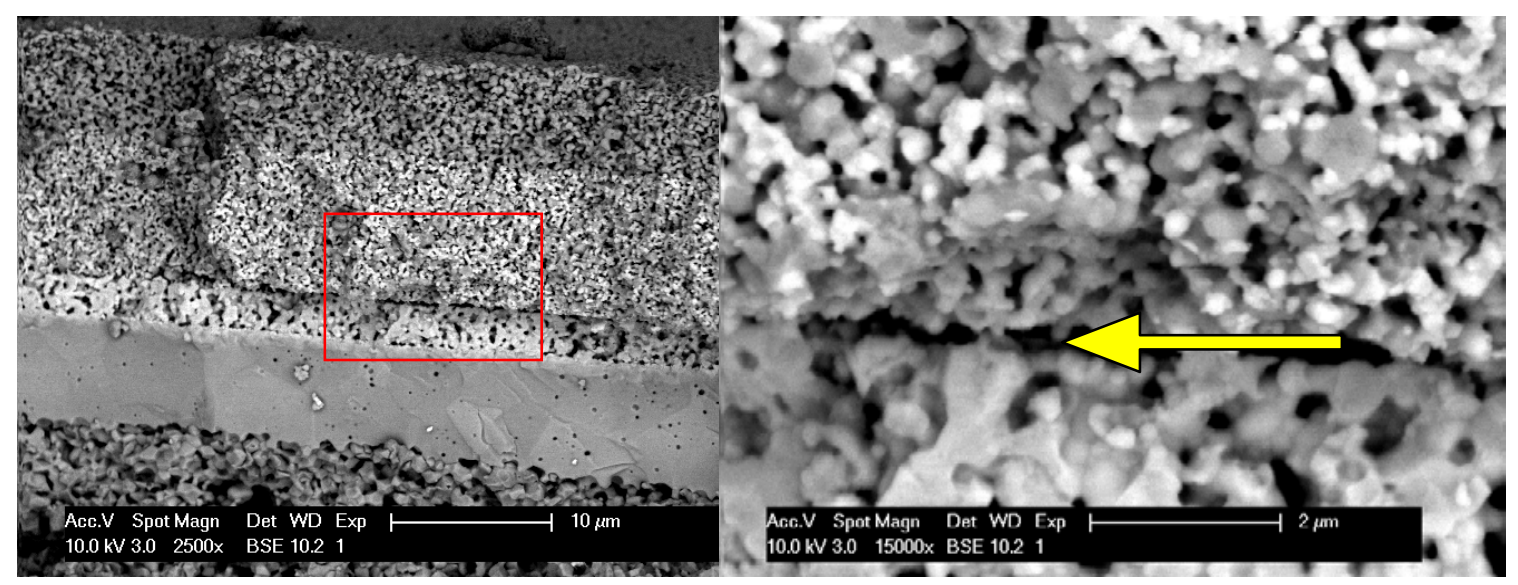

Figure 4. Left: SEM picture of cell 143.111 (40LSC-60GDC) after 10 thermic cycles. Delamination has occurred between the ceria layer and the composite cathode layer. Right: The close-up view of the red rectangle shows clearly a gap between the ceria layer and the cathode composite layer.

SEM analysis has been carried out in order to investigate the cause of degradation (Figure 4). The different layers are visible on the left picture (from the top: pure LSC, LSC-GDC, ceria layer, electrolyte and anode). Along the cathode-ceria layer interface delamination is visible regularly. This could explain the significant degradation of performances during the thermic cycles.

25LSC-75GDC. The last tested cell with LSC-GDC composite cathode had a 75\% content of GDC (cell 164.11), and underwent 40 thermic cycles. The performances before the thermic cycling were slightly better than the two other cells (Figure 5 and 8) with a current density of $1060\left[\mathrm{~mA} / \mathrm{cm}^{2}\right]\left(0.8 \mathrm{~V}, 780^{\circ} \mathrm{C}\right)$, corresponding to a power density of $848\left[\mathrm{~mW} / \mathrm{cm}^{2}\right]$. After $10 \mathrm{TC}$ the current density decreased from 1060 to 890 $\left[\mathrm{mA} / \mathrm{cm}^{2}\right]$, representing a power and current density loss of $1.6 \%$ per cycle. However the cell exhibited 3 different rates of degradation during the experiment. For the first 8 thermic cycles the loss was significant, $1.6 \%$ average power density loss per cycle, comparable to the previously tested cells. But after the $9^{\text {th }}$ cycle the rate of degradation decreased to $1.2 \%$ per cycle and the degradation appeared to be insignificant from the $30^{\text {th }}$ to the $40^{\text {th }}$ and last thermic cycles (Figure 8 and 9). The current density dropped to $776\left[\mathrm{~mA} / \mathrm{cm}^{2}\right]$ after 40 cycles, representing a power and current density loss of $0.7 \%$ per cycle. SEM images of this cell showed no visible delamination between the cathode and the ceria layer (Figure 6), the greater amount of ceria in the composite layer appeared to have protected the layer from delamination.

The figure 7 shows impedance spectroscopy of the cell at 2 [A] at $15 \mathrm{TC}$ and $26 \mathrm{TC}$. The results show an increase of the first semicircle at high frequency (from 17 to 22 $\mathrm{m} \Omega . \mathrm{cm}^{2}$ ), which could be linked to charge transfer at interfaces. The ohmic resistance (xintercept) does not visibly change and reads about $0.2\left[\Omega . \mathrm{cm}^{2}\right]$. 


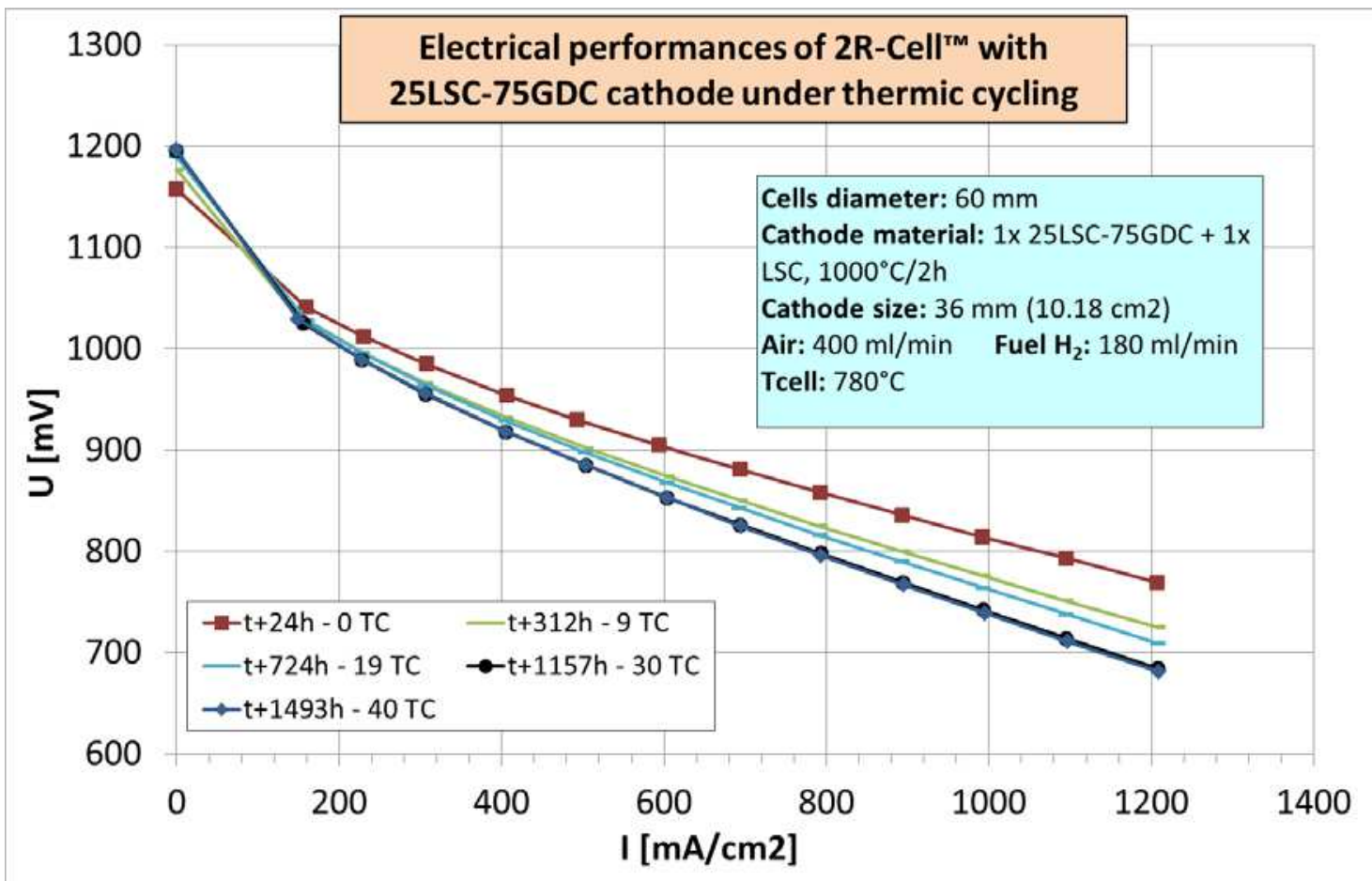

Figure 5. 2R-Cell with 25LSC-75GDC cathode. After 40 thermic cycles the average power density loss per cycle is $0.7 \%\left(0.8 \mathrm{~V}, 780^{\circ} \mathrm{C}\right)$. During the last 10 cycles $\left(30^{\text {th }}\right.$ to $\left.40^{\text {th }}\right)$ no degradation is recorded.

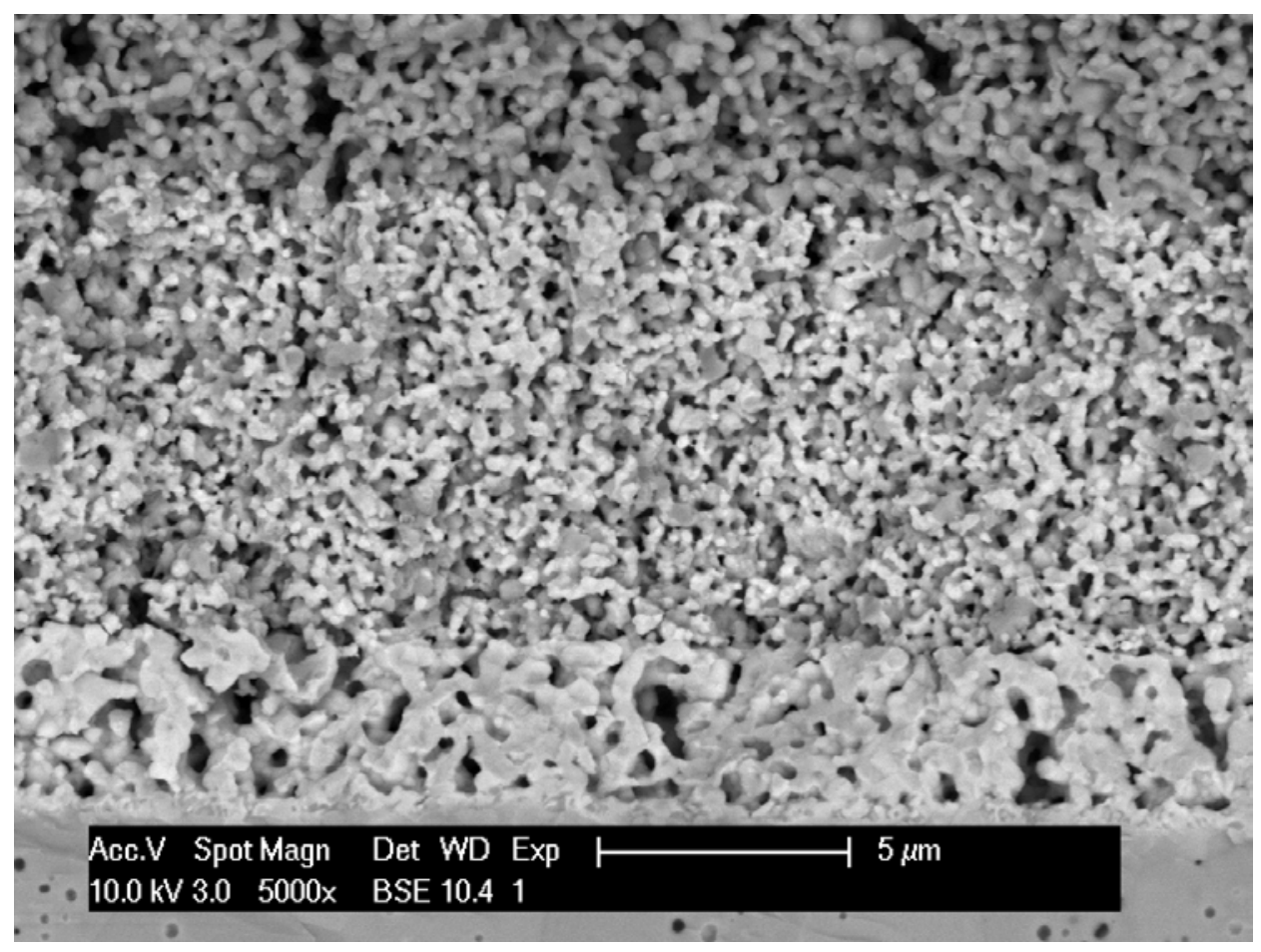

Figure 6. SEM picture of cell 164.11 (25LSC-75GDC) after 40 thermic cycles. No delamination was visible across the ceria layer-cathode interface. 


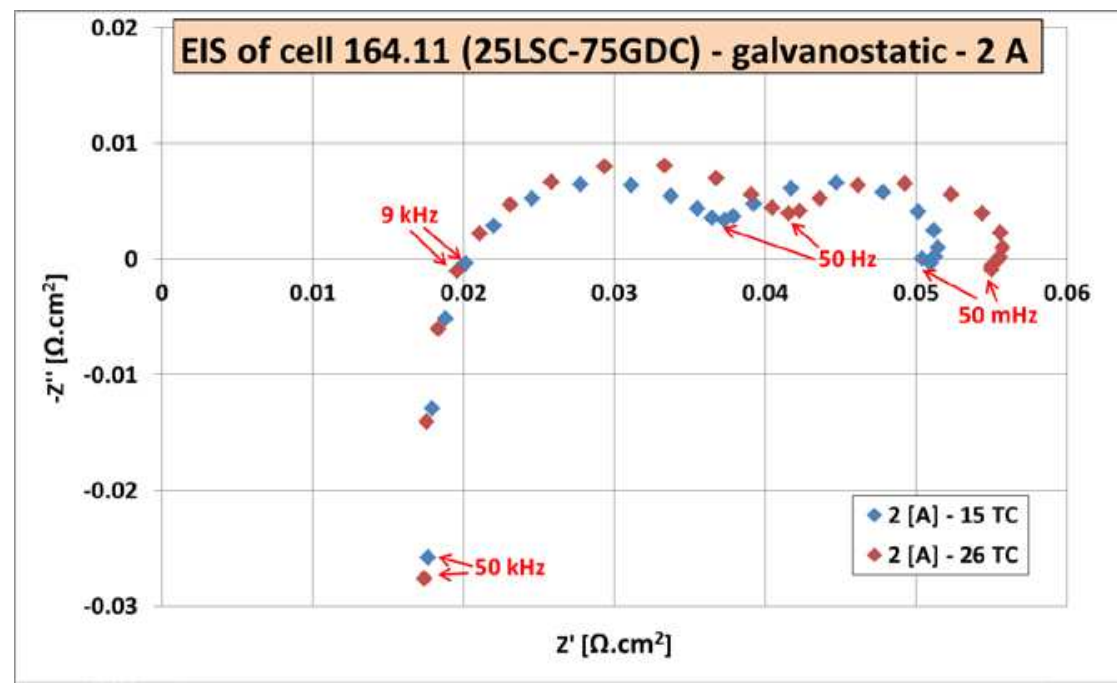

Figure 7. Nyquist plot of EIS of cell 164.11 at $780^{\circ} \mathrm{C}$, in blue after 15 thermic cycles and in red after 26 cycles. Current was set at $0.2\left[\mathrm{~A} / \mathrm{cm}^{2}\right]$. The ohmic resistance has not increased (stayed at about $0.2 \Omega . \mathrm{cm}^{2}$ ). The first semicircle at high frequency has increased in size.

\section{$\underline{\text { LSCF Cathode }}$}

A 2R-Cell equipped with a LSCF cathode was tested at EPFL during 1500 hours and was subjected to 20 thermic cycles and 20 redox cycles. I-V curves were recorded between each cycle to monitor the degradation, at $780^{\circ} \mathrm{C}$ and $180 \mathrm{ml} / \mathrm{min}$ of $\mathrm{H}_{2}$. The power density loss was much lower than LSC-GDC cathodes $(0.6 \%$ per cycle) (Figure 8$)$. Figure 9 shows the evolution of the ASR during the thermic cycling at 5 [A], which shows an average increase of $1.3\left[\mathrm{~m} \Omega . \mathrm{cm}^{2}\right](0.3 \%)$ per cycle. No delamination between the cathode and the ceria buffer layer could be observed during SEM analysis of the cell. This could explain the lowest degradation of the tested cells in this study.

Redox Cycles. The cell equipped with LSCF tested at EPFL was subjected to 20 redox cycles after the thermic cycles. The redox cycling consists of replacing the fuel by air for at least 1 hour, until the voltage drops to almost 0 . Then fuel is fed again to the cell and the circuit is closed when the OCV is reached. I-V curves were recorded after each cycle. The amplitude of degradation was similar as for thermic cycles with an increase of 1.8 $\left[\mathrm{m} \Omega . \mathrm{cm}^{2}\right](0.5 \%)$ per cycle. SEM images of the tested cell after $20 \mathrm{TC}$ and $20 \mathrm{RC}$ showed no observable delamination between anode and electrolyte. Detailed results and discussion about this experiment will be published by EPFL for the SOFC-XIV in Glasgow.

\section{$\underline{\text { LSC-LSCF Comparison }}$}

The power density at $0.8 \mathrm{~V}$ and $780{ }^{\circ} \mathrm{C}$ in function of the number of thermic cycle is plotted below (Figure 8) for the 4 cells presented in this paper. Contrary to the LSCGDC cathodes, the LSCF equipped cell has a significantly higher area specific resistance and a lower power density, but the cell is less sensible to thermic cycles and the ASR increase seems constant (Figure 9 and Table I). However the small number of thermic cycle gives no indication of long term behavior 


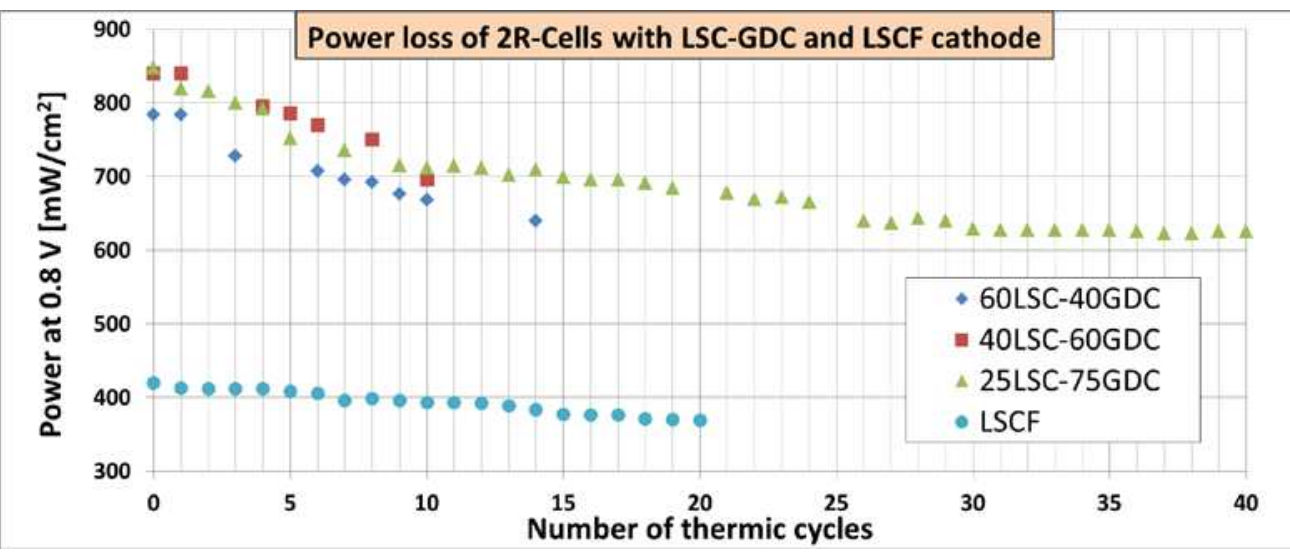

Figure 8. Power density loss of tested cells at $0.8 \mathrm{~V}$ and $780{ }^{\circ} \mathrm{C}$.

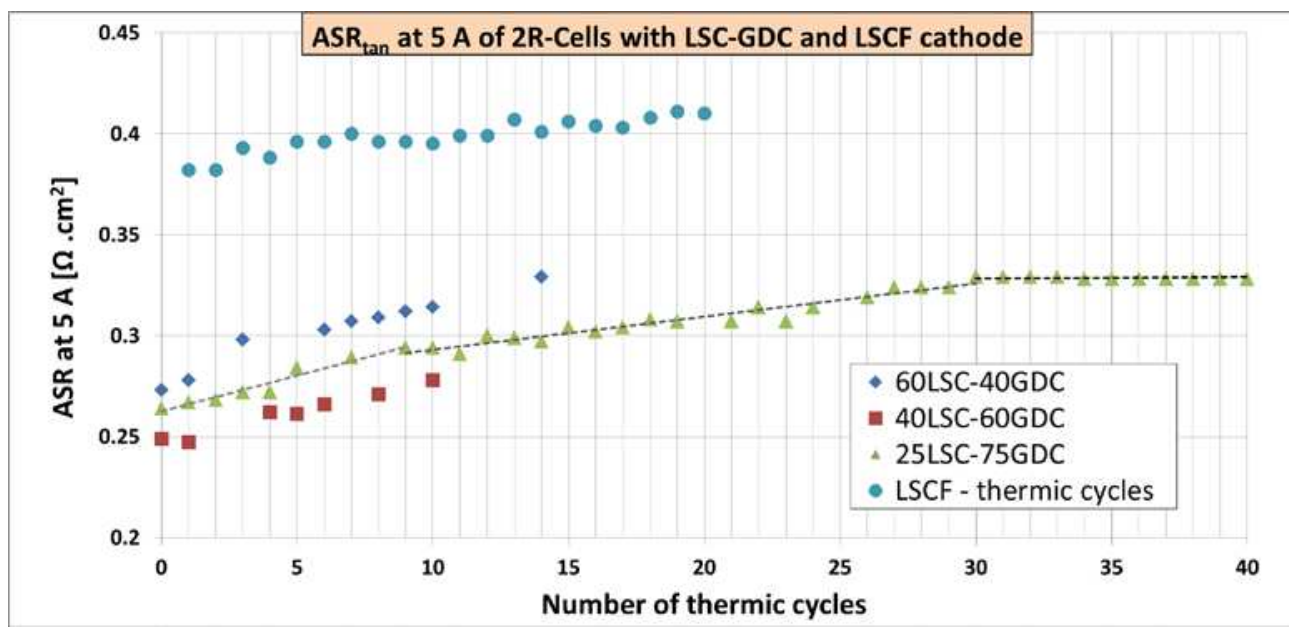

Figure 9. Summary of the computed $\mathrm{ASR}_{\tan }$ of the tested cells. Cells equipped with LSC based cathode have a significantly lower ASR than the LSCF. For the 25LSC-75GDC cell three different rates of degradation are observed.

Table I below summarizes for each cell the initial area specific resistance and power density, with corresponding average ASR increase and power loss for 10 and total number of thermic cycles.

TABLE I. Summary of results, $\mathrm{LSC}=\mathrm{La}_{0.5} \mathrm{Sr}_{0.5} \mathrm{CoO}_{3}, \mathrm{LSCF}=\mathrm{La}_{0.6} \mathrm{Sr}_{0.4} \mathrm{Co}_{0.2} \mathrm{Fe}_{0.8} \mathrm{O}_{3}, \mathrm{GDC}=20 \%$ mol. gadolinium doped ceria. All measures were done in the Open Flanges test Set Up at $780^{\circ} \mathrm{C}, 180$ $\mathrm{ml} / \mathrm{min}$ of $\mathrm{H}_{2}$ and $400 \mathrm{ml} / \mathrm{min}$ of air.

\begin{tabular}{|c|c|c|c|c|c|c|}
\hline $\begin{array}{c}\text { Cathode } \\
\text { (tested } \\
\text { by) }\end{array}$ & $\begin{array}{c}\text { Initial ASR } \\
\text { at } 5[\mathrm{~A}] \\
{\left[\Omega . \mathrm{cm}^{2}\right]}\end{array}$ & $\begin{array}{c}\text { Initial power } \\
\text { at } 0.8[\mathrm{~V}] \\
{\left[\mathrm{mW} / \mathrm{cm}^{2}\right]}\end{array}$ & \multicolumn{2}{|c|}{$\begin{array}{l}\text { Average ASR increase at } \\
5[\mathrm{~A}] \text { per thermic cycle } \\
{[\%] \text { (number of cycles) }}\end{array}$} & \multicolumn{2}{|c|}{$\begin{array}{c}\text { Average power loss at } \\
0.8[\mathrm{~V}] \text { per thermic cycle } \\
{[\%] \text { (number of cycles) }}\end{array}$} \\
\hline $\begin{array}{l}\text { 40GDC } \\
\text { (Fiaxell) }\end{array}$ & 0.273 & 789 & $1.5(10)$ & 1.5 (14) & $\mathbf{1 . 5}(10)$ & $1.3(14)$ \\
\hline $\begin{array}{l}\text { LSC40- } \\
\text { 60GDC } \\
\text { (Fiaxell) }\end{array}$ & 0.249 & 840 & $1.2(10)$ & $1.2(10)$ & $1.7(10)$ & $1.7(10)$ \\
\hline $\begin{array}{l}\text { LSC25- } \\
\text { 75GDC } \\
\text { (Fiaxell) }\end{array}$ & 0.264 & 848 & $1.1(10)$ & $\mathbf{0 . 6}(40)$ & $1.6(10)$ & $\mathbf{0 . 7}(40)$ \\
\hline $\begin{array}{l}\text { LSCF } \\
\text { (EPFL) }\end{array}$ & 0.382 & 410 & $0.3(10)$ & $0.3(20)$ & $\mathbf{0 . 6}(10)$ & $0.6(20)$ \\
\hline
\end{tabular}




\section{Conclusion}

LSC based cathode cells offer high performances $\left(790-850\left[\mathrm{~mW} / \mathrm{cm}^{2}\right]\right.$, at $0.8 \mathrm{~V}$ and $780^{\circ} \mathrm{C}$ ), but degrade when subjected to thermic cycles. All the LSC-GDC composite cathodes had a power loss of more than $1 \%$ per cycle (for 10 cycles). The SEM images suggest that this degradation is caused by delamination between the ceria layer and the composite layer of the cathode. The 25LSC-75GDC cell had a degradation rate of $1.1 \%$ per cycle for the first 9 cycles, and then the rate decreased between the $9^{\text {th }}$ and $30^{\text {th }}$ thermic cycles. After that degradation became insignificant. SEM analysis showed no visible delamination occurring, contrary to the other LSC-GDC cells.

On the other hand, the LSCF based cathode cell showed a constant rate of degradation ( $0.3 \%$ ASR increase per cycle), which had the same order of magnitude during redox cycles $(0.5 \%)$. This cell has however lower performances than LSC-based cathode cells $\left(410 \mathrm{~mW} / \mathrm{cm}^{2}\right)$, at $780^{\circ} \mathrm{C}$ and $\left.0.8 \mathrm{~V}\right)$. The power output of LSC-GDC cells after $40 \mathrm{TC}$ remains higher, even though there is less degradation in the LSCF cell. The cathode with a $75 \%$ weight amount of GDC surprisingly gives the best nominal (before TC) electrochemical results and provides a cell with a power output of $621\left[\mathrm{maw} / \mathrm{cm}^{2}\right]$ (at 0.8 $\mathrm{V}$ and $780^{\circ} \mathrm{C}$ ) after 40 thermic cycles.

\section{References}

1. G. Di Domenicantonio, Pascal Briois, Alain Billard, R. Ihringer, SOFC-XIII, ECS Trans., 57(1) (2013).

2. Raphael Ihringer, SOFC-XII, ECS Trans., 35(1) (2011).

3. R. Ihringer, Jan Van herle, and A.J. McEvoy, in Solid Oxide Fuel Cells V, U.Stimming, S.C. Singhal, H. Tagawa and W. Lehnert, Editors, PV 97-40, p. 340, The Electrochemical Society Proceedings Series,Pennington, NJ (1997). 